\title{
Improve the System Efficiency of Pumping Wells
}

\section{HongQing Dong ${ }^{1, a}$, Jun Wang ${ }^{2, b}$,Wei Wen ${ }^{1}$, ShuJun Zhang ${ }^{1}$, JianXun $\mathrm{Li}^{1}$, ChunXu Liu ${ }^{1}$, JinHui Wei ${ }^{1}$, SuQin Peng ${ }^{1}$, JinJie Li ${ }^{1}$, Yin Zhang ${ }^{1}$}

${ }^{1}$ No.2 Oil production Plant, Huabei Oilfield Company, PetroChina, Bazhou, Hebei 065700, China ${ }^{2}$ Gas storage management division, Huabei Oilfield Company, PetroChina, Langfang, Hebei 065000, China

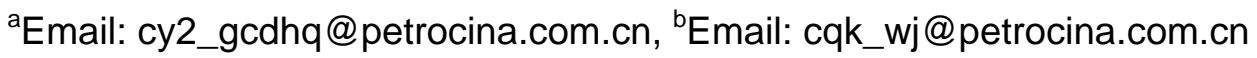

Keywords: Chaheji oilfield; Pumping Wells; System Efficiency; Factors

Abstract: System efficiency of pumping wells is an important indicator of whether the oil well running well. The higher the single well system efficiency, the more balance in whole system, and the less consumption of electricity. The results of test show that the pumping wells average system efficiency of Chaheji oilfield is $25.5 \%$, and the efficiency of surface and underground are $59.4 \%$ and 42.9\%. There is much promotion space for improvement. In this paper, by analyzing the influential factors of system efficiency, we put forward the methods including optimizing ground equipment parameters, rational using the wellbore technology, enhancing the formation energy to further improve the efficiency of the system.

\section{Introduction}

Pumping wells are the dominant position in Chaheji oil production. The number of wells in Chaheji is 514 in total, including 512 pumping wells, which accounted for $99 \%$ of all. The daily oil production are $825 \mathrm{t}$ and $820 \mathrm{t}$, respectively. Pumping unit is still the main way in oil production. Currently, annual electricity consumption of all Chaheji oil field pumping wells is $5400 \times 10^{4} \mathrm{~kW} \cdot \mathrm{h}$. To improve the pumping well efficiency of system can bring huge economic benefit. Therefore, the research of system efficiency and influence factors of pumping wells have an important practical significance.

\section{The system efficiency of pumping wells in Chaheji oil field}

The test of system efficiency mainly includes YBC-2000R integrated system tester, three-phase active energy meter, echo instrument, pressure gauge, etc [1]. Device is shown in Fig.1.

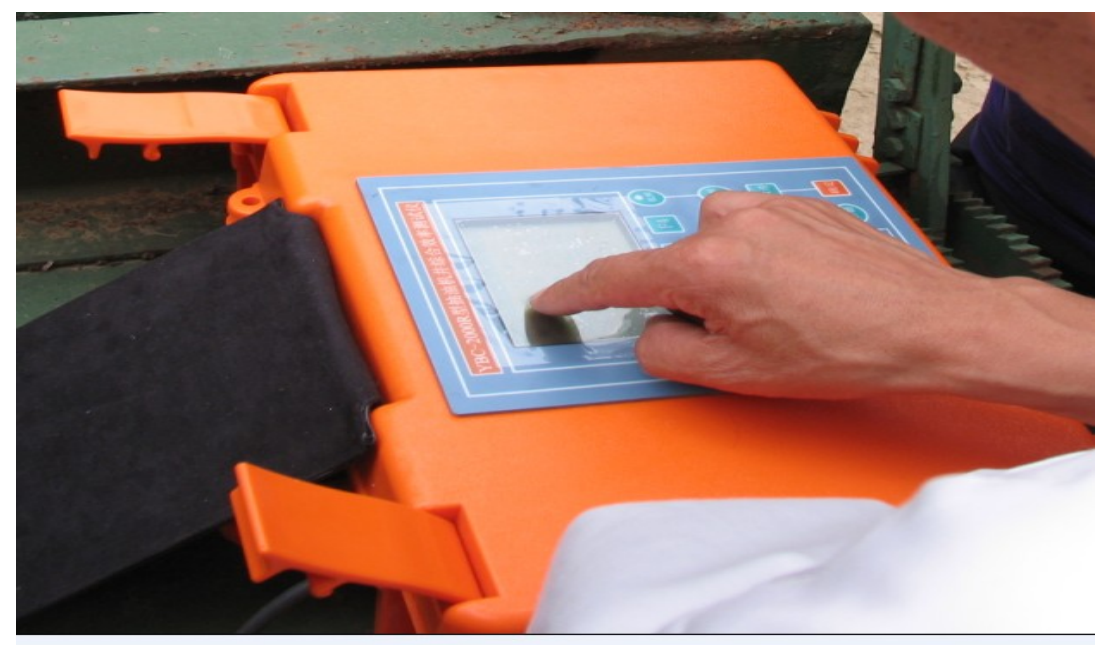

Fig. 1 YBC-2000R integrated system tester

The results of system efficiency test in 2014 show that average system efficiency of pumping wells in Chaheji oil field was $25.5 \%$, ground efficiency was $42.9 \%$ and underground efficiency was $42.9 \%$. 
Most of the ground efficiency is higher when the underground efficiency is lower. Data is shown in Table 1.

Table 1 The system efficiency of pumping wells in Chaheji oil field

\begin{tabular}{ccccc}
\hline Units & $\begin{array}{c}\text { The number of } \\
\text { wells }\end{array}$ & $\begin{array}{c}\text { Ground } \\
\text { efficiency(\%) }\end{array}$ & $\begin{array}{c}\text { Underground } \\
\text { efficiency(\%) }\end{array}$ & $\begin{array}{c}\text { System } \\
\text { Efficiency(\%) }\end{array}$ \\
\hline ChaBei & 109 & $61.3 \%$ & $45.6 \%$ & $26.9 \%$ \\
ChaZhong & 145 & $58.9 \%$ & $38.8 \%$ & $23.4 \%$ \\
ChaNan & 258 & $58.1 \%$ & $42.3 \%$ & $24 \%$ \\
Total & 512 & $59.4 \%$ & $42.2 \%$ & $25.5 \%$ \\
\hline
\end{tabular}

\section{The ways to improve the system efficiency of pumping wells}

\subsection{Application of energy-saving pumping units and motors}

Application of energy pumping unit and the motor is the main way to improve the efficiency of the ground. To improve work efficiency, we should avoid excessive considerations about reserve capacity of the equipment and improve motor power factors in the selection of equipment [2]. The energy-saving motors accounted for $90 \%$ in Chaheji oilfield.

\subsection{Adjust the balance of pumping unit}

The way of adjusting the balance of the system to improve the efficiency is small investment and achieved quickly. Balance adjustment of pumping unit can reduce the motor power, reduce consume for nothing, and improve the ground efficiency and power consumption of single well [3]. The balance should be controlled between 80\% 120\%. Data is shown in Table 2.

\section{Table 2 Comparison of system efficiency before and after the balance index adjustment}

\begin{tabular}{ccccc}
\hline $\begin{array}{c}\text { Well } \\
\text { number }\end{array}$ & $\begin{array}{c}\text { Balance index } \\
\text { before adjustment }\end{array}$ & $\begin{array}{c}\text { Balance index } \\
\text { after adjustment }\end{array}$ & $\begin{array}{c}\text { Efficiency of the } \\
\text { system before } \\
\text { adjustment }\end{array}$ & $\begin{array}{c}\text { Efficiency of the } \\
\text { system after } \\
\text { adjustment }\end{array}$ \\
\hline Cha74-36 & 0.58 & 0.85 & $43.6 \%$ & $44.9 \%$ \\
Cha74-206 & 6.16 & 1.02 & $21.2 \%$ & $22.8 \%$ \\
Cha12-291 & 0.6 & 0.95 & $25.1 \%$ & $25.8 \%$ \\
\hline
\end{tabular}

\subsection{Adjust the operating parameters of the pumping unit to increase pump efficiency}

To the wells which have enough liquid supplying, we should increase the pumping parameters and improve the lift height. To the wells which have no enough liquid supplying, we should reduce the frequency of pump or take between open systems to improve single well liquid supply situation. In this way, it can reduce power consumption and improve pump efficiency, the system efficiency is also improved obviously [4-5]. After adjusting the system, the underground efficiency of Cha33-28 well increased from $37 \%$ to $46 \%$. Data is shown in Table 3.

Table 3 Comparison of the efficiency of Cha33-28 wells

\begin{tabular}{cccccc}
\hline & $\begin{array}{c}\text { Stroke } \\
(\mathrm{m})\end{array}$ & $\begin{array}{c}\text { Frequency } \\
\text { (beats/min) }\end{array}$ & $\begin{array}{c}\text { Daily Liquids } \\
\text { production } \\
(\mathrm{t} / \mathrm{d})\end{array}$ & $\begin{array}{c}\text { Fluid level } \\
(\mathrm{m})\end{array}$ & $\begin{array}{c}\text { Underground } \\
\text { efficiency } \\
(\%)\end{array}$ \\
\hline Before adjustment & 4.8 & 5 & 11 & 1871 & 37 \\
After adjustment & 4.8 & 4 & 19 & 1812 & 46 \\
\hline
\end{tabular}

\subsection{Increase the formation energy}

Reperforating can improve the formation fluid situation and increase oil production. After reperforating, the daily fluid production of Cha71-53 well increased from $5 t$ to $18 \mathrm{t}$, the pump efficiency increased from $20 \%$ to $88 \%$, and the system efficiency increased from $17 \%$ to $27 \%$. 
Strengthening water supply can lay the foundation of reducing and controlling the liquid supply shortage area well. Chaheji oilfield has 29 wells turn to injection wells in 2015, so that the average pump efficiency of the entire area increased by $5 \%$. The system efficiency of wells in this area also increased.

\subsection{Comprehensive treatment of rod string and tubing wear}

Partial wear have a significant impact on the efficiency of the pumping system, so governance about partial wear phenomenon has a positive effect on enhancing the efficiency of the system [6]. Studies suggest that the application of rod centralizers and anti-eccentric wear section hoop can effectively reduce the wear of the rod string and the load of polish rod.

Currently, Chaheji oilfield has basically formed a wearproof technology mainly consisting of lining pipe + anti-eccentric wear righting lever + lever + aggravate chemical corrosion. It can effectively reduce the oil side wear. Tools are shown in Fig.2.
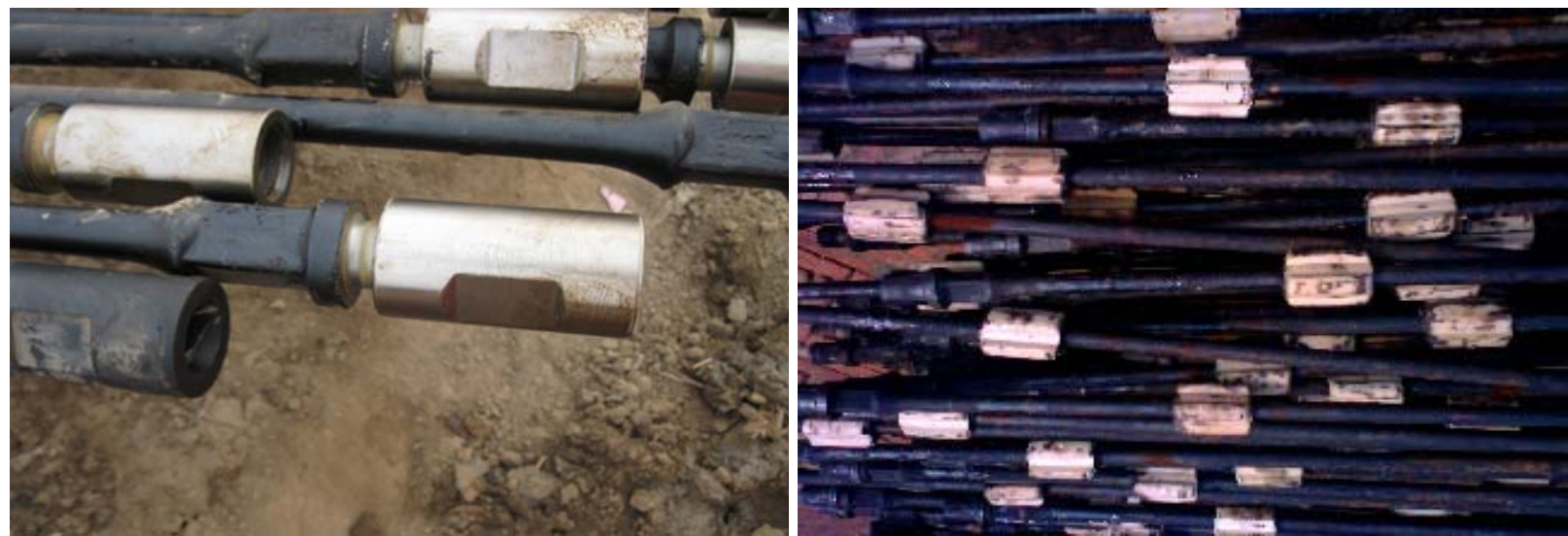

Fig. 2 Preventing partial abrasion tools

\subsection{Optimizing design scheme of the oil well}

The program of well optimization is an important means to improve the system efficiency of pumping well.

With the depth of the pump stroke increasing, the stroke loss also increases. If you have no oil pumping technology matching well with deep well, and ultimately the system efficiency will decrease with the increase of depth [7]. Pump parameters and downhole tools should be selected according to the specific conditions of each well, so as to accommodate gas, sand, wax and other well conditions requirements.

\section{Achievements}

In 2015, the technicist drew up management plan of system efficiency in allusion to the oil wells which have the potential to improve, meanwhile we adjust the ground and the underground parameters. Adjust ground parameters for 166 times, and adjust the underground parameters for 115 times. The system efficiency of pumping wells in Chaheji oilfield increased from $25.5 \%$ in 2014 to $27.6 \%$ in 2015 , and 1.8 million $\mathrm{kWh}$ were saved.

\section{Conclusions}

5.1 The main factors affecting the efficiency of the ground is low efficiency of the motor itself. In addition, poor balance pumping unit is also a factor.

5.2 The main factors affecting the underground efficiency is the low discharge coefficient of pump, the small effective head of delivery, partial wearing of oil wells, sand production, etc.

5.3 Due to the current target of tube rod pump design is the output or string strength, rather than the system efficiency, the project design has a strong impact on underground efficiency. 


\section{References}

[1] Kilgore J J, Tripp $\mathrm{H}$ A, Hunt $\mathrm{Jr}$ C L. Walking beam pumping unit system efficiency measurements[C]//SPE Annual Technical Conference and Exhibition. Society of Petroleum Engineers, 1991.

[2] Malinowski J, Livoti W C, Kaunitz D C. Consider System Efficiency for Increased Savings[C]//Carbon Management Technology Conference. Carbon Management Technology Conference, 2012.

[3] Takacs G. Ways to obtain optimum power efficiency of artificial lift installations[C]//SPE Oil and Gas India Conference and Exhibition. Society of Petroleum Engineers, 2010.

[4] Cox B R, Williams B J. Methods To Improve the Efficiency of Rod-Drawn Subsurface Pumps[C]//SPE Production Operations Symposium. Society of Petroleum Engineers, 1989.

[5] Giangiacomo L A, Hill D R. Optimizing pumping well efficiency with smart fluid-level controller technology[C]//SPE mid-continent operations symposium. 1999: 617-624.

[6] Mitchell R F. Effects of well deviation on helical buckling[J]. SPE Drilling \& Completion, 1997, 12(01): 63-70.

[7] Gault R H. Designing a sucker-rod pumping system for maximum efficiency[J]. SPE production engineering, 1987, 2(04): 284-290. 